\title{
Estimation of growth rate, biosilica, protein and lipid content in locally isolated Fragellaria vaucheria
}

\author{
Yosef J. Ismaeel Al-Shahrii \\ Biology Department / College of Education / University of Mosul, \\ Mosul, Iraq \\ Received \\ 28 / 08 / 2007 \\ Accepted \\ 03 / 03 / 2008
}

\section{الخلاصة}

قم الحصول على عزلة منطحلب Fragellaria vaucheria الت الع الـ ق ق سم

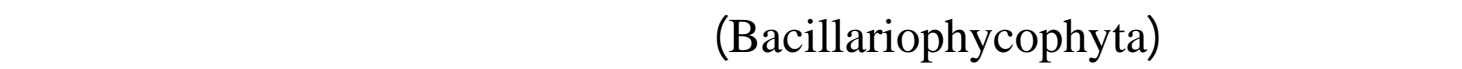
بلغت أقصى إنتلجية للطحلب من الكتلة الحيوية (580 ملغم/لتر) بعدسبعة اليلم من التحضين .

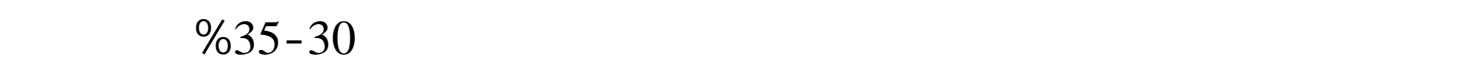

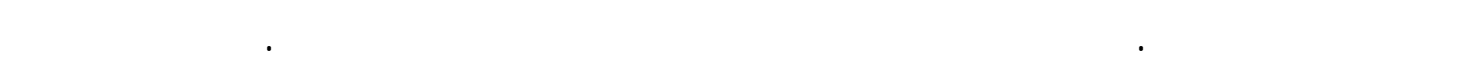
اللشعة تحت الحمراء للسيليكا الففصولة قاوتها اله حد كبير.

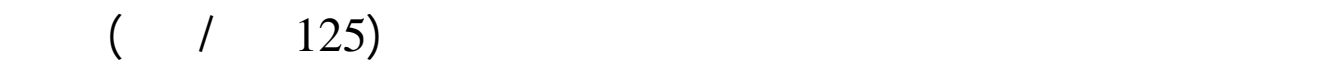

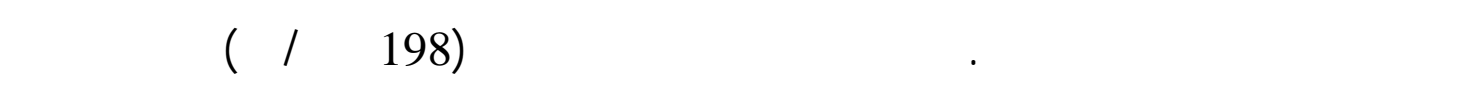

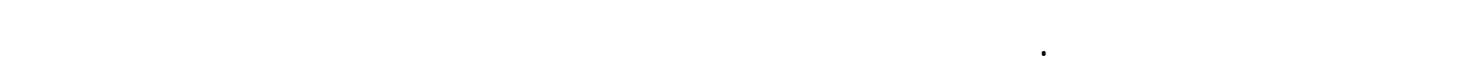

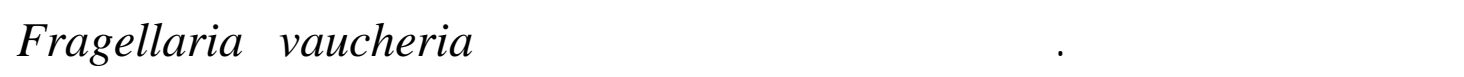
ينمو بمدى ولسع من الس الهيدروجيني. وان أفضل نمو تحقق عند الاس الهيدروجيني 7.6 .

\section{Abstract}

The study was conducted in Mosul city, northern Iraq to obtain a local isolate of the algal, Fragellaria vaucheria (Bacillariophycophyta) . Maximum biomass (58 mg/l) was obtained after seven days of incubation. The ratio of precipitated biosilica in the cellular walls ranged between 30 to $35 \%$ of the dry weight of the biomass. The amount of biosilica increased with progress of incubation period. The infra red spectrum test showed the high purity of isolated silica. 
The protein content increased with increase of algal growth and reached $125 \mathrm{mg} / \mathrm{l}$ after fifteenth days of incubation, Maximum lipid content (198 mg/l) was obtained after eleven days of incubation. Generally final $\mathrm{pH}$ value was higher than the initial one. The algal Fragellaria vaucheria have a wide $\mathrm{pH}$ range and the optimum $\mathrm{pH}$ for growth was 7.6 .

\section{Introduction}

The current study on algal physiology and biotechnology has not taken sufficient attention in Iraq. The most previous studies were emphasized on ecology and taxonomy algae ${ }^{(1)}$. Blue green algae were cultivated for measurement of some metabolic compounds ${ }^{(2,3)}$. The global interest with algae belongs to their economic importance, on the other hand, significant determination were caused by some algae, surrounding ecosystem. Also, the algae were considered as a rich source for many chemical compounds such as drugs, antibiotics and enzymes ${ }^{(4)}$. The agar, a supportment constituent of cultivated media was extracted from some Rhodophycophyta ${ }^{(5)}$.

The algae were used as animal feeds and human being food-stuff $f^{(6)}$. Because of high protein and lipid content of some algae, they were cultivated for production of biomass ${ }^{(7,8)}$. The determination of biomass had a significant importance in aquatic ecosystem, and for this reason many parameters were taken into consideration such as:

dry weight, size of cells, chlorophyll, organic carbon content of cells and additional parameters such as like protein and lipid content of cells $^{(9)}$. On the other hand, the algae had severe negative effect on human being activities, first of these statements was considered as pollutants of water refining stations through their rich growth in the refining filters. Also, some algae hand ability to accrue poisonous substances for aquatic organisms and even human beings ${ }^{(10)}$.

The Bacillariophycophyta were considered as one of the major algae division as species and varieties. The distinct character for this division was presence of high silica with large content in the cell walls. The silica part of the cell wall dose not change after death of diatoms cells, so that high number of old diatoms cell walls were sedimented in any water body, and these sedimentation may reach big thickness which is called diatomatceous earth ${ }^{(11)}$.

Many studies emphasized the diatoms ability of the sedimentation of silica in their cell walls through absorption of soluble silicon in its environment through active transport ${ }^{(12)}$. The researchers were indicated that biosilica had important role in cellular $\mathrm{pH}$ modulation and 
appropriate for enzymatic system of some important physiological activities ${ }^{(12)}$.

The genus Fragellaria considered one of the common genera of Bacillariophycophyta. The recorded species of Fragellaria in Iraq are about 27 spp. $^{(13)}$. The species of this genus were either unicellar or colony. The morphology of Fragellaria can be described as fallows, the form of frustul ranged between linear like to lanceolat form and terminats with delicate apex, also, there is real raphy or pseudoraphy on frustul surface. The number of stria rangs from 11 to 19 for each $10 \mathrm{M}$. The Fragellaria $s p$. is mostly growing together with many other algae species either green algae, blue-green algae or diatoms. The growth of Fragellaria is effected by environmental $\mathrm{pH}^{(14)}$.

Because of the wide distribution of Fragellaria vaucheria in water resources and it causes pollution for many local water bodies in Mosul city, so that, the present study aimed to obtain pure cultures of Fragellaria vaucheria. Also determination of silica ratio in the cellular walls, protein and lipid content and daily growth rate of this algal where done.

\section{Materials and Methods \\ Microorganism and preservation:}

A local specimens of the Fragellaria vaucheria, isolated from Shallalat station in Mosul was used throughout. the algal was grown on $\mathrm{CHU}_{10}$ medium and preserved at $4{ }^{\circ} \mathrm{C}$ and sub cultured every two weeks.

\section{Culture medium :}

The algal was cultured on $\mathrm{CHU}_{10}$ medium which consisted of the following $(\mathrm{gm} / \mathrm{l})^{(15)}$.

$\mathrm{Ca}\left(\mathrm{NO}_{3}\right)_{2}, 0.04-\mathrm{K}_{2} \mathrm{HPO}_{4}, 0.01-\mathrm{MgSO}_{4} \cdot 7 \mathrm{H}_{2} \mathrm{O}, 0.025-\mathrm{Na}_{2} \mathrm{CO}_{3}, 0.02$ $-\mathrm{Na}_{2} \mathrm{SiO}_{3}, 0.025-\mathrm{FeCl}_{2}, 0.02$. The $\mathrm{pH}$ was adjusted between 7.6-7.8 by $\mathrm{NaHCO}_{3}(1 \mathrm{~N})$ or concentration $\mathrm{HCl}$. Then sterilized at $121^{\circ} \mathrm{C}$ and 1 atmospheric pressure in the autoclave. The solid $\mathrm{CHU}_{10}$ medium was prepared by adding Agar $10 \mathrm{gm} / \mathrm{l}$ to $\mathrm{CHU}_{10}$ liquid medium. After sterilization the medium was distribution in petridishes which were used later in algal growth and isolation.

\section{Isolation and culture conditions :}

The algal specimen was cultured on $\mathrm{CHU}_{10}$ medium under sterilized conditions by paering either few water droplets or little quantity of soil in petridishes containing $\mathrm{CHU}_{10}$ medium. The petridishes were incubated at the following condition: continued illumination 2500 lux and temperature $28^{\circ} \mathrm{C}$ for $4-6$ weeks. The growth of algal colonies were 
observed, then the algae were examined with compound microscope to determine growing colonies types. The growing colonies were transfered into petridishes containing sold $\mathrm{CHU}_{10}$ medium to obtain pure cultures of the Fragellaria vaucheria. After obtaining good growth of the algal, the cultures were transfered to sterilized liquid $\mathrm{CHU}_{10}$ medium in conical flasks $250 \mathrm{ml}$ containing $100 \mathrm{ml}$ of the medium.

The flasks were incubated in shaking incubator $100 \mathrm{rpm}$, illumination 2500 lux and $28^{\circ} \mathrm{C}$, for seventh days ${ }^{(3)}$.

\section{Analysis procedures :}

\section{Estimation of $F$. vaucheria biomass productivity :}

After termination of incubation period, the flasks were randomly withdrown from shaking incubator. Final $\mathrm{pH}$ for each flask was recorded. Then, the content of each flask was centrifuged (5000 rpm) for $30 \mathrm{~min}$ to precipitate the algal cells. The precipitated cells were collected in weighted small and dry glass dishes. Later, the dishes were dried in electric oven at $60^{\circ} \mathrm{C}$ for 24 hours. Again, the dishes were weighted by digital balance and the net weight of algal cells was recorded.

\section{Isolation and measurement of Biosilica:}

The digestion of the content of each flask of F.vaucheria was done by concentrated sulphuric acid and potassium dichromate. After digestion the content was centrifuged $(5000 \mathrm{rpm})$ for $30 \mathrm{~min}$., after that, cell precipitate were ignited by furnace at $850^{\circ} \mathrm{C}$ in for 3 hours and weighted $^{(14)}$.

\section{Infrared spectrum of biosilica :}

Infrared spectrum of isolated biosilica dispersed in $\mathrm{KBr}$ discs was obtained using Unicom sp infrared spectrophotometer.

\section{Total protein content determination :}

The total protein content was estimated by modified Lowry method $^{(16)}$. After complete destruction of algal cells by freezing and thawing. This method was repeated for 10 times to ensure complete destruction of all algal cells, after that, the flask content was centrifuged with $3000 \mathrm{rpm}$ for $10 \mathrm{~min}$. Bovine albumin serum was used as standard solution to prepared standard curve of the protein.

\section{Lipid content determination:}

Lipid content in algal cells was estimated according to Toro and Ackermann $^{(17)}$. A standard lipid solution (pure olive oil) was used to estimate total lipid concentration . 


\section{Results and Discussion}

Fragellaria vaucheria identification :

Fragellaria spp as most of diatoms were characterized by brownish color. The algae was found to show lateral symmetry this proved Fragellaria $s p$ to be one genus of penniales order. Cells of Fragellaria were found either as solitary or as star-shaped coloies.

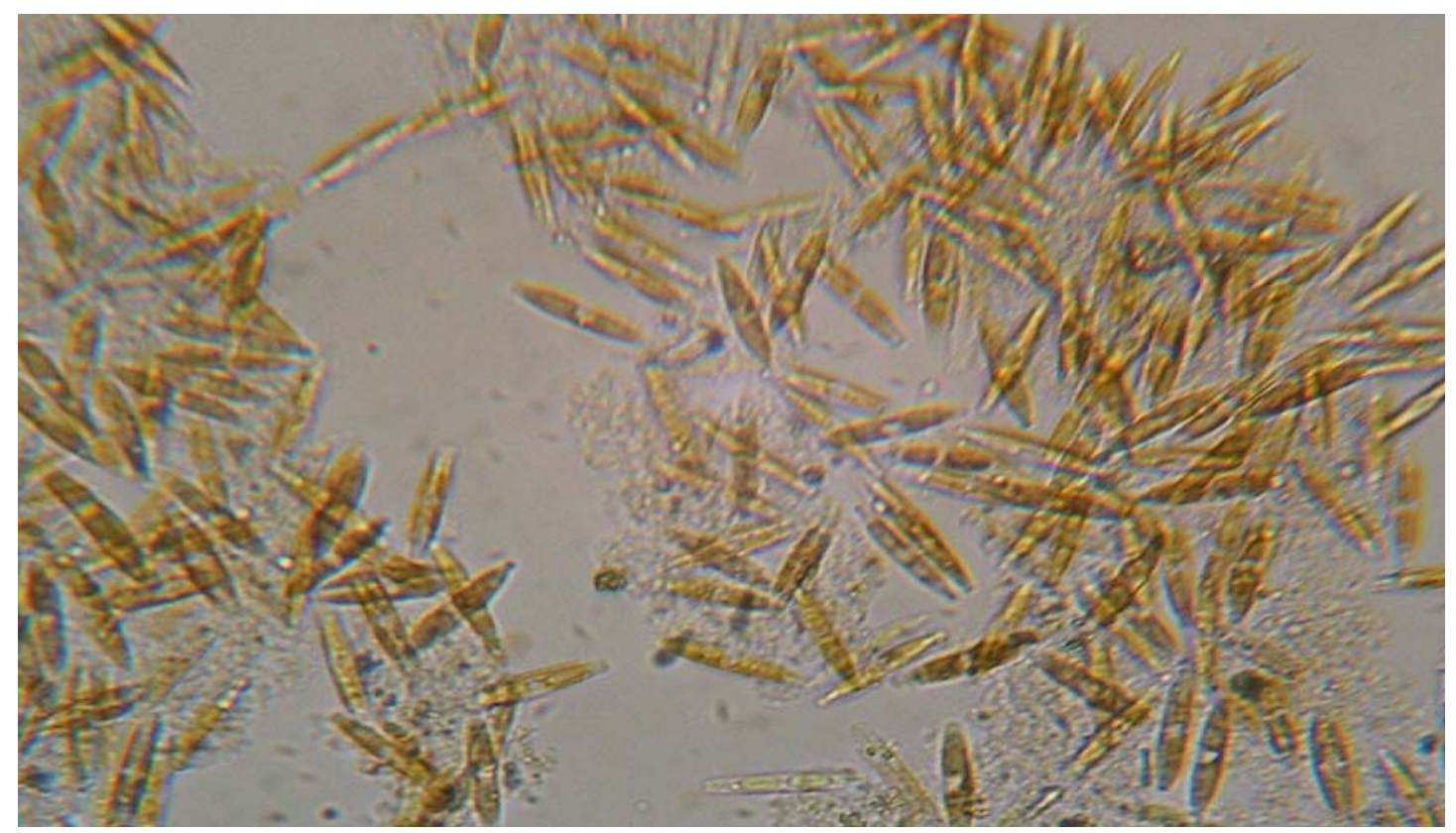

Figure(1): aggregated cells of the algal Fragellaria vaucheria (40x)

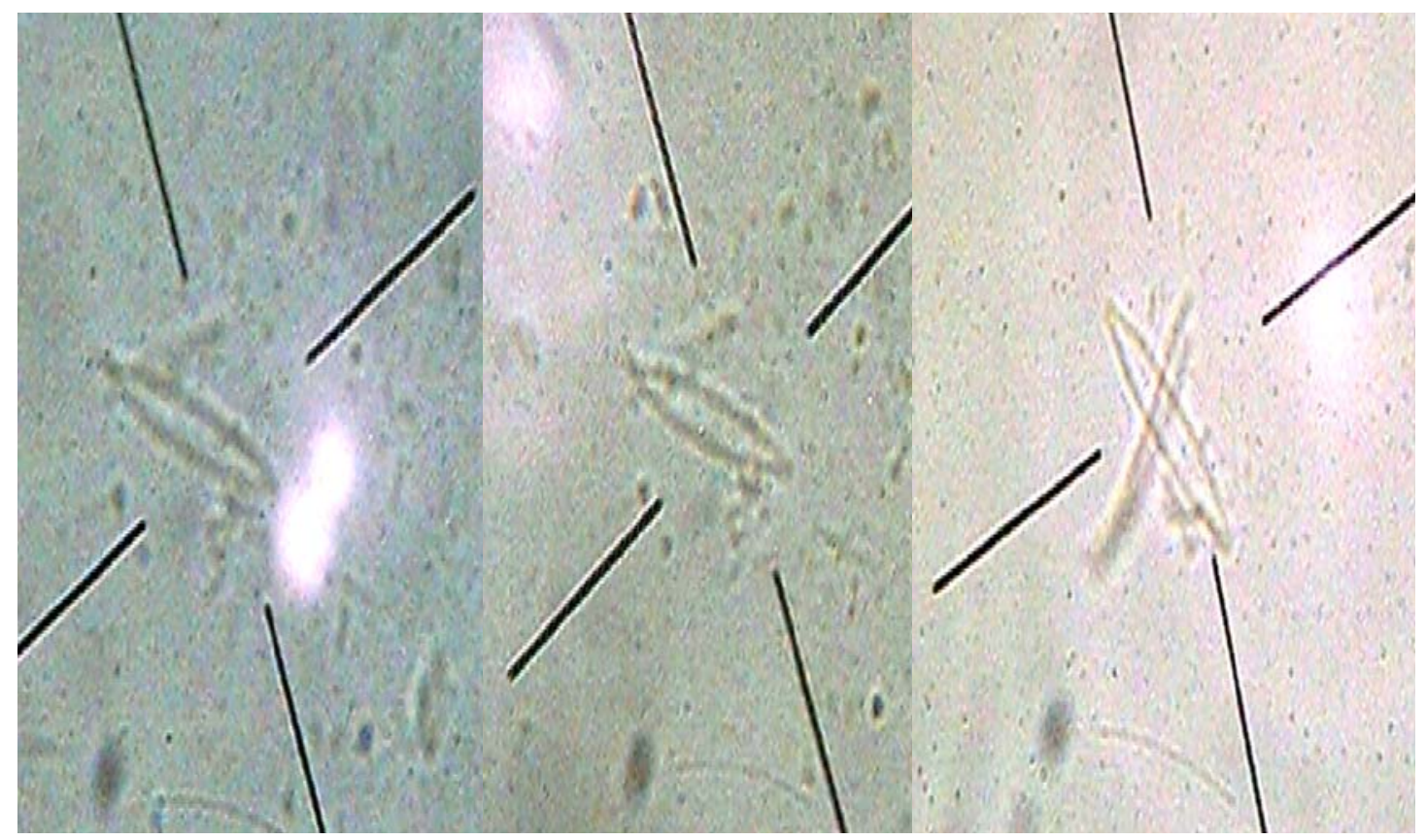

Figure(2): Fragellaria vaucheria. Algal after digestion with $\mathrm{H}_{2} \mathrm{SO}_{4}(40 x)$ 
The isolated algae were found to have linear to linear lanceolate frustul and the frustul terminated with rounded apices. Also the frustul was found to have pseudoraphy. The number of stria ranged between 1219 for each 10 micrometer (figure 1,2). These features of algae according to patrik and Remmer ${ }^{14}$ and hadi et al ${ }^{18}$ confirmed that the isolated algae is Fragellaria vaucheria.

\section{Effect of incubation period:}

The results showed that incubation periods affect the following parameters: Fagellaria vaucheria growth biosilica, protein, and lipid content and final $\mathrm{pH}$ (table, 1); the growth of the algal increased with incubation periods until the seventh day in which maximum growth (580 $\mathrm{mg} /$ liter) was attired. The algal growth gradually declined with increasing of the incubation period up to fifteenth day. This growth variables were mainly attributed to consumption of some important nutrients. The quantity of biosilica in the cellular walls increased with the increasing of the incubation period up to $180 \mathrm{mg} / \mathrm{l}$ at the fifteenth day of incubation. These findings might belong to silica part of the cell wall which did not chang after cell death and decay of the diatom cells ${ }^{(5)}$. Also, the protein content of the algal cells raised with incubation period (table 1). It was found that the quantity of total protein $125 \mathrm{mg} / \mathrm{l}$ after fifteenth days of incubation, the protein content of the alga was not coincided with algal growth. These results agreed with Al-Juboori ${ }^{(3)}$ who found that protein content of some algae increased with incubation period.

The present results showed that lipid content increased with incubation period up to eleventh day and then declind gradually up to fifteenth day as illustrated in table (1). These results are emphasized by most other surveyed literatures $(8,11)$. The results also showed that final $\mathrm{pH}$ increased significantly as compared with initial $\mathrm{pH}$.

Variation of $\mathrm{pH}$ during incubation period is attributed directly to photosynthesis and consumption of $\mathrm{CO}_{2}$ during growth of alga (quantum $1,2)$ as growth led to production and liberation of alkaloids.

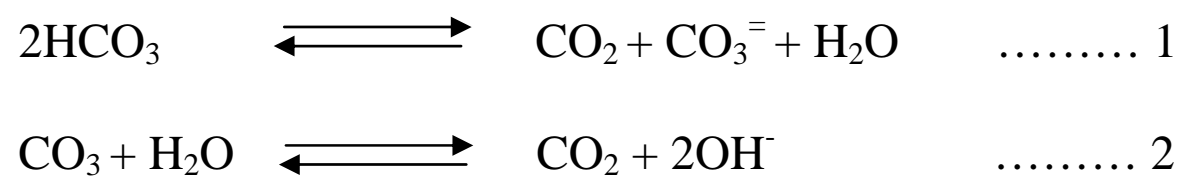

These results agreed with Edward and cilia ${ }^{(19)}$.

According to the mention results the incubation period (7 days) was chosen as optimized incubation period in the next experiments . 
Table (1): Effect of incubation periods on algal growth, biosilica, protein and lipid contents.

\begin{tabular}{|c|c|c|c|c|c|}
\hline $\begin{array}{l}\text { Incubation } \\
\text { Period (day) }\end{array}$ & $\begin{array}{c}\text { Biomass } \\
\mathrm{mg} / \mathrm{l}\end{array}$ & $\begin{array}{c}\text { Biosilica } \\
\mathrm{mg} / \mathrm{l}\end{array}$ & $\begin{array}{c}\text { Protein content } \\
\mathrm{mg} / \mathrm{l}\end{array}$ & $\begin{array}{c}\text { Lipid content } \\
\mathrm{mg} / \mathrm{l}\end{array}$ & $\begin{array}{c}\text { Final } \\
\mathrm{pH}\end{array}$ \\
\hline 1 & $\begin{array}{c}42 \\
(0.02) \\
\end{array}$ & $\begin{array}{c}12 \\
(0.12) \\
\end{array}$ & $\begin{array}{c}10 \\
(0.02) \\
\end{array}$ & $\begin{array}{c}50 \\
(0.79) \\
\end{array}$ & $\begin{array}{c}7.68 \\
(0.91) \\
\end{array}$ \\
\hline 2 & $\begin{array}{c}200 \\
(0.05) \\
\end{array}$ & $\begin{array}{c}69 \\
(0.02) \\
\end{array}$ & $\begin{array}{c}19 \\
(1.22) \\
\end{array}$ & $\begin{array}{c}66 \\
(1.11) \\
\end{array}$ & $\begin{array}{c}8.20 \\
(1.07) \\
\end{array}$ \\
\hline 3 & $\begin{array}{c}337 \\
(0.43)\end{array}$ & $\begin{array}{c}107 \\
(0.02)\end{array}$ & $\begin{array}{c}025 \\
(0.50)\end{array}$ & $\begin{array}{c}95 \\
(0.04)\end{array}$ & $\begin{array}{l}8.990 \\
(1.11)\end{array}$ \\
\hline 4 & $\begin{array}{c}366 \\
(0.79)\end{array}$ & $\begin{array}{c}111 \\
(0.05)\end{array}$ & $\begin{array}{c}30 \\
(0.79)\end{array}$ & $\begin{array}{c}109 \\
(0.91)\end{array}$ & $\begin{array}{c}9.90 \\
(1.22)\end{array}$ \\
\hline 5 & $\begin{array}{c}480 \\
(0.09) \\
\end{array}$ & $\begin{array}{c}144 \\
(0.07) \\
\end{array}$ & $\begin{array}{c}033 \\
(0.03) \\
\end{array}$ & $\begin{array}{c}112 \\
(0.04) \\
\end{array}$ & $\begin{array}{c}9.20 \\
(0.00) \\
\end{array}$ \\
\hline 6 & $\begin{array}{c}500 \\
(0.07)\end{array}$ & $\begin{array}{c}150 \\
(0.70)\end{array}$ & $\begin{array}{c}40 \\
(0.09)\end{array}$ & $\begin{array}{c}153 \\
(0.04)\end{array}$ & $\begin{array}{l}9.15 \\
(0.00\end{array}$ \\
\hline 7 & $\begin{array}{c}580 \\
(0.91)\end{array}$ & $\begin{array}{c}164 \\
(0.24)\end{array}$ & $\begin{array}{c}54 \\
(0.25)\end{array}$ & $\begin{array}{c}171 \\
(0.81)\end{array}$ & $\begin{array}{c}9.11 \\
(0.03)\end{array}$ \\
\hline 8 & $\begin{array}{c}560 \\
(1.22) \\
\end{array}$ & $\begin{array}{c}164 \\
(0.03) \\
\end{array}$ & $\begin{array}{c}65 \\
(0.81 \\
\end{array}$ & $\begin{array}{c}182 \\
(0.07) \\
\end{array}$ & $\begin{array}{c}9.81 \\
(0.00) \\
\end{array}$ \\
\hline 9 & $\begin{array}{c}540 \\
(0.43) \\
\end{array}$ & $\begin{array}{c}166 \\
(0.25) \\
\end{array}$ & $\begin{array}{c}058 \\
(0.04) \\
\end{array}$ & $\begin{array}{c}189 \\
(0.42) \\
\end{array}$ & $\begin{array}{c}8.80 \\
(0.03) \\
\end{array}$ \\
\hline 10 & $\begin{array}{c}527 \\
(0.05)\end{array}$ & $\begin{array}{c}167 \\
(0.01)\end{array}$ & $\begin{array}{c}66 \\
(0.07)\end{array}$ & $\begin{array}{c}194 \\
(0.00)\end{array}$ & $\begin{array}{c}8.00 \\
(0.01)\end{array}$ \\
\hline 11 & $\begin{array}{c}520 \\
(0.58) \\
\end{array}$ & $\begin{array}{c}167 \\
(0.02) \\
\end{array}$ & $\begin{array}{c}071 \\
(0.00) \\
\end{array}$ & $\begin{array}{c}198 \\
(0.42) \\
\end{array}$ & $\begin{array}{c}8.74 \\
(0.20) \\
\end{array}$ \\
\hline 12 & $\begin{array}{c}50 \\
(0.72) \\
\end{array}$ & $\begin{array}{c}168 \\
(0.03) \\
\end{array}$ & $\begin{array}{c}86 \\
(0.09) \\
\end{array}$ & $\begin{array}{c}171 \\
(0.02) \\
\end{array}$ & $\begin{array}{c}8.78 \\
(0.91) \\
\end{array}$ \\
\hline 13 & $\begin{array}{c}488 \\
(0.17)\end{array}$ & $\begin{array}{c}168 \\
(0.15)\end{array}$ & $\begin{array}{c}95 \\
(0.04)\end{array}$ & $\begin{array}{c}163 \\
(0.017)\end{array}$ & $\begin{array}{c}8.61 \\
(0.03)\end{array}$ \\
\hline 14 & $\begin{array}{c}460 \\
(0.17) \\
\end{array}$ & $\begin{array}{c}168 \\
(0.00) \\
\end{array}$ & $\begin{array}{c}108 \\
(0.15)\end{array}$ & $\begin{array}{c}15 \\
(0.72) \\
\end{array}$ & $\begin{array}{c}8.33 \\
(0.17) \\
\end{array}$ \\
\hline 15 & $\begin{array}{c}451 \\
(0.05)\end{array}$ & $\begin{array}{c}171 \\
(0.02)\end{array}$ & $\begin{array}{c}125 \\
(1.00)\end{array}$ & $\begin{array}{c}144 \\
(0.91)\end{array}$ & $\begin{array}{c}8.20 \\
(0.17)\end{array}$ \\
\hline
\end{tabular}

Values in parenthesis reflected to standard deviation .

\section{Effect of pH on the algal growth, Biosilica and protein and lipid contents:}

The results (table 2) showed that highest growth $52 \mathrm{mg} / \mathrm{l}$ was obtained at $\mathrm{pH} 7.6$ after 7 days of incubation. The growth of algae decrease with increase of $\mathrm{pH}$ and no growth was obtained at $\mathrm{pH} 11.6$. It many be concluded from these results that Fragellaria vaucheria has a wide $\mathrm{pH}$ range their interprets the wide distribution of this algae in various environmental ${ }^{(1,17) \text {. }}$

Increase in silica content of $F$. vaucheria coincided with growth rate, therefore highest biosilica content $150 \mathrm{mg} / \mathrm{l}$ was obtained at $\mathrm{pH} 7.6$. 
Silica absorption and it sedimentation in celluler walls are correlated to growth and depend on cell viability and activity ${ }^{11}$.

Also the results (table 2) showed that maximum protein content $63 \mathrm{mg} / \mathrm{l}$ was obtained at $\mathrm{pH} 7.6$ with respect to lipid, maximum. Lipid content $(180 \mathrm{mg} / \mathrm{l})$ was record at $\mathrm{pH}$ 7.6. Both protein and lipid content declined with increase in $\mathrm{pH}$ value. Generally final $\mathrm{pH}$ increased in compare to initial $\mathrm{pH}$. The results also showed that at higher initial $\mathrm{pH}$ value 10.6 , 11.6 no algal growth was observed .

Table (2): Effect of different values pH number on algae growth , biosilica, protein and lipid contents

\begin{tabular}{|c|c|c|c|c|c|}
\hline $\begin{array}{c}\text { Initial } \\
\mathrm{pH}\end{array}$ & $\begin{array}{c}\text { Biomass } \\
\mathrm{mg} / \mathrm{l}\end{array}$ & $\begin{array}{c}\text { Biosilica } \\
\mathrm{mg} / \mathrm{l}\end{array}$ & $\begin{array}{c}\text { Protein content } \\
\mathrm{mg} / \mathrm{l}\end{array}$ & $\begin{array}{l}\text { Lipid content } \\
\mathrm{mg} / \mathrm{l}\end{array}$ & $\begin{array}{c}\text { Final } \\
\mathrm{pH}\end{array}$ \\
\hline 2.6 & $\begin{array}{c}1 \\
(0.40)\end{array}$ & $\begin{array}{c}2 \\
(0.09)\end{array}$ & $\begin{array}{l}0.000 \\
(0.00)\end{array}$ & $\begin{array}{c}0.00 \\
(0.00)\end{array}$ & $\begin{array}{c}2.80 \\
(0.08)\end{array}$ \\
\hline 3.6 & $\begin{array}{c}120 \\
(0.22) \\
\end{array}$ & $\begin{array}{c}36 \\
(0.28) \\
\end{array}$ & $\begin{array}{c}15 \\
(0.00) \\
\end{array}$ & $\begin{array}{c}55 \\
(0.08) \\
\end{array}$ & $\begin{array}{c}6.42 \\
(0.03) \\
\end{array}$ \\
\hline 4.6 & $\begin{array}{c}22 \\
(0.30) \\
\end{array}$ & $\begin{array}{c}66 \\
(0.56) \\
\end{array}$ & $\begin{array}{c}28 \\
(0.57) \\
\end{array}$ & $\begin{array}{c}62 \\
(1.12) \\
\end{array}$ & $\begin{array}{c}7.90 \\
(0.01) \\
\end{array}$ \\
\hline 5.6 & $\begin{array}{c}400 \\
(1.08)\end{array}$ & $\begin{array}{c}123 \\
(0.22)\end{array}$ & $\begin{array}{c}44 \\
(0.10)\end{array}$ & $\begin{array}{c}165 \\
(0.24)\end{array}$ & $\begin{array}{c}9.30 \\
(0.03)\end{array}$ \\
\hline 6.6 & $\begin{array}{c}500 \\
(0.07) \\
\end{array}$ & $\begin{array}{c}148 \\
(1.70)\end{array}$ & $\begin{array}{c}50 \\
(1.20) \\
\end{array}$ & $\begin{array}{c}142 \\
(0.01)\end{array}$ & $\begin{array}{c}9.39 \\
(0.09) \\
\end{array}$ \\
\hline 7.6 & $\begin{array}{c}520 \\
(0.00) \\
\end{array}$ & $\begin{array}{c}150 \\
(0.10) \\
\end{array}$ & $\begin{array}{c}63 \\
(0.02) \\
\end{array}$ & $\begin{array}{c}180 \\
(0.06) \\
\end{array}$ & $\begin{array}{r}9.48 \\
(0.01) \\
\end{array}$ \\
\hline 8.6 & $\begin{array}{c}400 \\
(0.06) \\
\end{array}$ & $\begin{array}{c}104 \\
(0.40) \\
\end{array}$ & $\begin{array}{c}58 \\
(0.07) \\
\end{array}$ & $\begin{array}{c}138 \\
(0.03) \\
\end{array}$ & $\begin{array}{c}9.48 \\
(0.80) \\
\end{array}$ \\
\hline 9.6 & $\begin{array}{c}370 \\
(0.90) \\
\end{array}$ & $\begin{array}{c}89 \\
(0.14) \\
\end{array}$ & $\begin{array}{c}25 \\
(0.30) \\
\end{array}$ & $\begin{array}{c}130 \\
(0.30) \\
\end{array}$ & $\begin{array}{c}9.50 \\
(0.30) \\
\end{array}$ \\
\hline 10.6 & $\begin{array}{c}10 \\
(0.00) \\
\end{array}$ & $\begin{array}{c}2 \\
(0.00) \\
\end{array}$ & $\begin{array}{c}0.00 \\
(0.00) \\
\end{array}$ & $\begin{array}{l}0.00 \\
(0.00 \\
\end{array}$ & $\begin{array}{c}10.5 \\
(0.00) \\
\end{array}$ \\
\hline 11.6 & $\begin{array}{c}0.00 \\
(0.00) \\
\end{array}$ & $\begin{array}{c}0.00 \\
(0.00) \\
\end{array}$ & $\begin{array}{c}0.00 \\
(0.00) \\
\end{array}$ & $\begin{array}{c}0.00 \\
(0.00) \\
\end{array}$ & $\begin{array}{c}11.6 \\
(0.00) \\
\end{array}$ \\
\hline
\end{tabular}

Values in parenthesis reflected to standard deviation .

\section{Infrared spectrum :}

To insure the purity of isolated biosilica of Fragellaria vaucheria cell wall this test were conducted. IR spectrum (figure 3) showed absorption peak at $1092 \mathrm{~cm}^{-1}$ this absorption confirms the presence of pure silica ${ }^{(20)}$. 


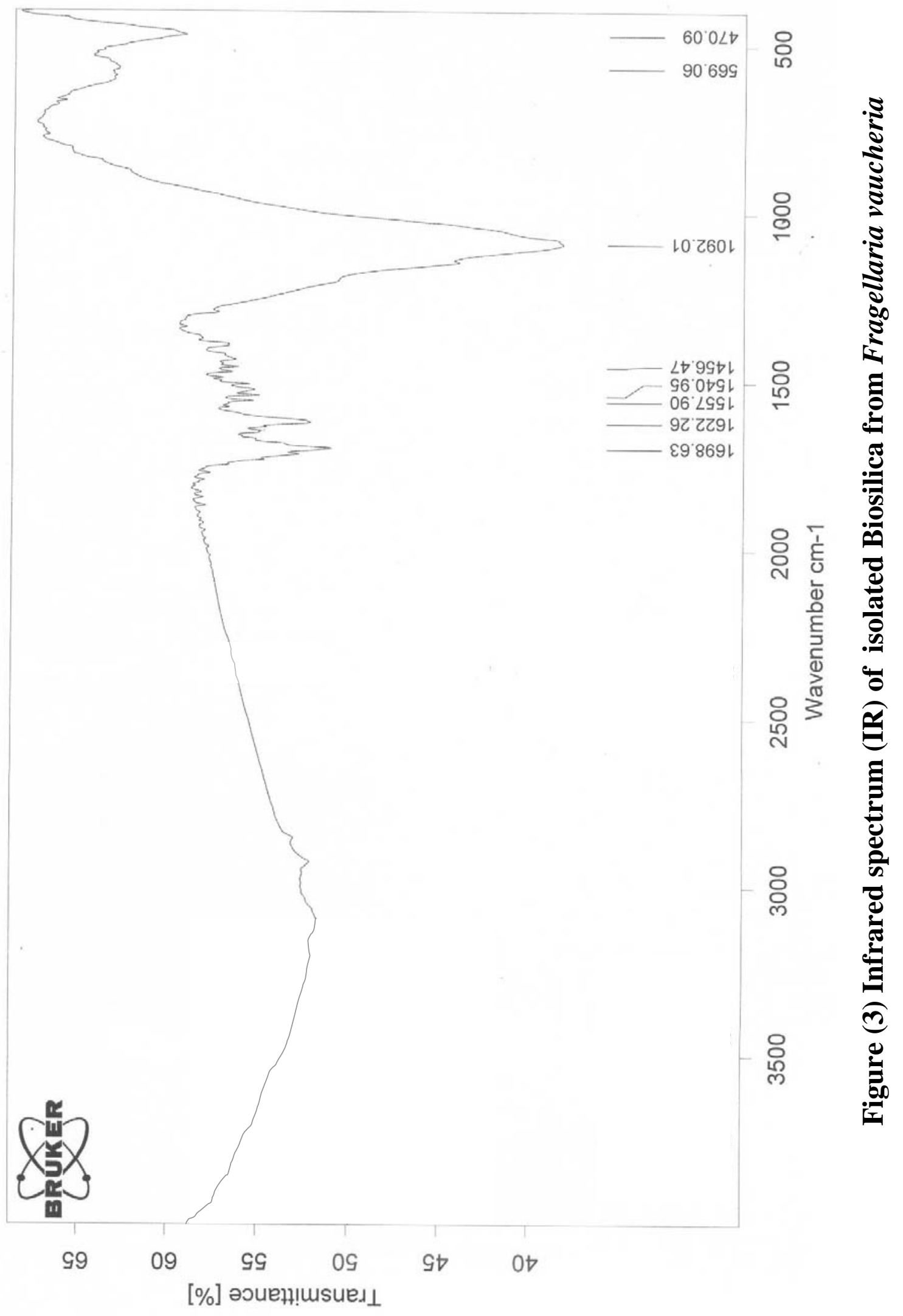




\section{Reference}

1. Al- Shahri. ph.D.Thesis. Dept. of Biology. College of Education. University of Mosul. (2006). (In Arabic)

2. Ali, H.A. M.Sc. Dept. Biology. College of Education for woman. University of Tikrit . (2006). (In Arabic) .

3. Al-Joubori, A.S. M.Sc. Thesis. College of Science. University of Salahdin (1989). (In English).

4. Paul, G.Becher and Karl, G. . J.Nat. Prod. 68: 1793-1795. (2005) .

5. Naguib, K. Abdulsalam,F. and Amin, R. . Vol.1 Algae and fungi. Unvi. of Mosul. Iraq. (1982).

6. Grima, E. Fernandes., F, Camacho. F and Chist, Y. n P.J. Bioteeh. $70: 231$ - 246. (1999) .

7. Have, A.A., volum and ultrastructure of marine diatoms. Marine Ecology . J. Vol . 142: 47-54. (1996).

8. Opute, F. I . Oxford university, J. 25: 823-826. (1974) .

9. Dillon, J, Phuc, A and Dubacq, J. . Monaco , 12 : 103 -107. (1993)

10. Ray, S; Bagchi, S. . New pht. J. 149 : 455-460 . (2001) .

11. Maulood, B.K.; Nithal, I.S. and Ibrahim, B. "Algae and Archagoniates" . Univ. of Baghdad - Iraq. (1990) .

12. Allen, J.M. and Francois, M.M. Science J. Vol. 297 : 1848-1850. (2002) .

13. Maulood, B. K. and Toma, J. J. Babylon. Univ. Vol.9: 1-71. (2004).

14. Patrick, R. and Reimer, C. W., Vol. 1 Monger. Acad. Nat. Sci., Newyourk. USA. (1966) .

15. Blod, H. C. and Wynne, M. J. "Introduction to the Algae Structure and Reproduction". $2^{\text {nd }}$. Prentice-Hall, Inc. Englewood cliffs. New Jersey, USA. (1985) .

16. Schacterle, G.R. and Pollack, J.K. . Anal. Biochem., Vol.51: 654655. (1973) .

17. Toro, G. and Ackermann, P. G. "Practical Clinical Chemistry". Little, Borwn and company, Boston. (1975).

18. Hadi, R. A.; Al-Saboonchi, A. and Haroon, Y.K. .Nova Hedwigia, Band XXXIX : 513-557. (1989).

19. Celia, Y. C. and Edward, G. D. Mar. Ecol. Prog. Ser. Vol. 109 : 83-94. (1994).

20. Khuthier, Abdul-Hussain; Al-Rawi, J. M. and Iraqi, M. A. "Absorption Spectroscopy of Organic Molecules". printed of mosul. Mosul University. 1985 . 